\title{
DIMENTIONS OF IMPROVEMENT THE PHYSICAL HEALTH OF PEOPLE WITH MENTAL ILLNESS
}

Dennis RELOJO

УАК $159.9: 616$

\section{Аеніс Релоджко \\ ВИМІРИ ВДОСКОНАЛЕННЯ ФІЗИЧНОГО ЗДОРОВ'Я У ЛЮДЕЙ З РОЗУМОВИМИ ВАДАМИ}

Mental disorders contribute significantly to the Global Burden of Disease, as four out of the ten diseases with the highest burden are psychiatric. Moreover, about a quarter of the population, develop one or more psychiatric and behavioural disorders during their lifetime. Unipolar depression ranges as the leading mental disorder with respect to disability with adjusted life years. The major psychiatric disorders like schizophrenia and depression are found in all cultures and result in significant disability. The cost of mental disorders worldwide needs receiving increasing recognition (Kastrup \& Ramos, 2007).

One could reasonably expect obesity, diabetes, or smoking to result in reduced physical health and shorter life; but for mental illness the link is not so intuitive. How could differences in psychological state make such an impact on, and impair the physical body. And yet, as countless studies are coming to show, a link does indeed exist.

For instance, in Portugal comprehensive information about access and patterns of use of mental health services in Europe is lacking. In Portugal, particularly the counsellor figure is yet to exist - where the orders connected with mental health eclectically, and bears an elitist seal among them, but also where status seems to be more essential that the patient's health - it has become difficult to effectively deal with this subject. This is, of course, is not unique in Portugal (Pinto-Coelho, 2017).

Over the past 30-40 years, general life expectancy across the world has been rising from around 61 years in 1980, to around 71 in 2015 (Wang et al., 2015). The subset of the population with a mental health disorder, however, have not benefitted from such a generous growth (Lawrence et al., 2013); and the average person with a mental illness can expect to live between 10-25 years lower than the general population (World Health Organization, n.d.; Lawrence et al., 2013). One reason is the greater propensity towards suicide among this population, and the primary focus has, for a long time, been on suicide-prevention strategies. But over $80 \%$ of early mortalities in people with mental illness are actually a direct result of comorbid general medical conditions (Lawrence et al., 2013). It is clear that the current care system is failing people with a mental illness and new solutions will need to be considered.

From the back pages of global medical reports and the footnotes of World Health Organization (Kolappa et al., 2013), mental illness is finally making it into the forefront of public health strategies. Unfortunately, much of this new wave of attention is being directed into mental illness as a problem of disability rather than one of

Copyright ( РЕЛОДЖО Деніс, Велика Британія (RELOJO Dennis, United Kingdom), 2018. 
mortality (Walker et al., 2015). It is true that of mortalities in mental illness, psychological symptoms are rarely the direct cause of death, but mental illness is a significant risk factor for many of the leading causes of death due to noncommunicable and communicable diseases worldwide (Lawrence et al., 2013). Indeed, a recent meta-analysis of mortality in mental illness has concluded that mental health conditions constitute a population attributable risk (PAR) of $14.3 \%$ and are, therefore, responsible for more than 8 million annual deaths worldwide, ahead of ischaemic heart disease, stroke, chronic obstructive pulmonary disease (COPD) and HIV / AIDS (Walker et al., 2015; World Health Organisation [no date]).

This huge death rate is partially attributable to an increased likelihood of people with a mental illness developing physical health problems. This is particularly the case in cardiovascular disease (CVD), by far the largest contributor to worldwide disease-related mortality, where diagnosis is as much as two and a half times more likely for people with major depressive disorder or schizophrenia (FrasureSmith and Lespŭrance, 2010; Curkendall et al., 2004), and may yet be even higher for people with bipolar disorder (Goldstein et al., 2009). The risk factor for type II diabetes mellitus (DM), responsible for 1.5 million deaths per year, is not too far behind with anywhere between a 1.5 to 2 times increased risk for people with severe mental illness (Campayo et al., 2011; Curkendall et al., 2004; Goldstein et al., 2009), while respiratory symptoms such as chronic bronchitis and emphysema are also far more likely to occur in psychiatric patients than in the general population (Himelhoch et al., 2004). Though the link with overall cancer prevalence is more controversial, people with schizophrenia are at a higher risk of breast, lung and digestive system cancers than the general population (Robson \& Gray, 2007; Spiegel \& Giese-Davis, 2003)

Prevalence elevations are not only confined to non-communicable disease, however. Mental illness is also associated with a greater chance of contracting many infectious diseases. By far, the largest contributor to the global death rates in this category is HIV/AIDS and there is evidence to suggest that people with severe mental illness are at as much as an eight times increased risk of contracting the disease (Scott and Happell, 2011; Robson \& Gray, 2007; Rosenberg et al., 2001; De Hert et al., 2011), especially in countries where the overall preva- lence of blood-borne infection is low (Hughes et al., 2016). Hepatitis B and C are also major risks for people with a severe mental illness with studies indicating anywhere between 5-11\% increase in incidence, and, worldwide, $20-25 \%$ of this population are estimated to be infected with hepatitis C (De Hert et al., 2011). Meanwhile, schizophrenia has been reported as being so intimately linked with tuberculosis in some parts of the world that there are dedicated wards set up for the treatment of both conditions (De Hert et al., 2011).

Education can also play a role. For instance, during the past decades, the way that researchers and educators understand and describe the process of reading has been revolutionised. The present article examines the current developments in reading abilities among second language readers. The developments are further discussed in terms of a theory of general second language proficiency encompassing both oral and written language. Implications on the nature of second language reading, the database in second language reading, text-and knowledge-driven operations in second language reading, and second language reading classroom factors have been provided. Assessment of comprehension is briefly reviewed, and recommendations are provided for theoretical, cultural, and educational implications (Relojo, dela Rosa, \& Pilao, 2016).

There are obviously severe underlying factors predisposing people with severe mental illness to diseases, but the problems also extend to treatment and prognosis. Mental illness is both a predictor for mortality and the severity of symptoms arising from physical health problems. In patients with myocardial infarction, for example, depressive symptoms are a significant predictor for death both at 6 and 18 months post-event, and the risk of dying from CVD is at least 25\% higher than the background rate for people with an anxiety disorder, personality disorder or schizophrenia (Hennekens et al., 2005; Roest, 2010; Moran et al., 2007) and more than two times higher for people with bipolar disorder (Roshanaei-Moghaddam and Katon, 2015). Patients with schizophrenia are one and a half times more likely to die from all types of cancer, and more than seven times from digestive system and testicular cancers (Tran et al., 2009). Severe mental illness is also associated with higher mortality for infectious disease including pneumonia and influenza, which in people suffering co-morbid bipolar disorder is around four times more likely to result in death (Crump 
et al., 2013). Worsened symptoms including functional impairment and reported pain have frequently been reported in people suffering mental illness for example in cancer (Spiegel \& Giese-Davis, 2003). Moreover, another study (Jones et al., 2008) found that people with schizophrenia, who were admitted to medical and surgical wards, were found to have significantly higher rates of infections, post-operative complications (including intensive care unit admission or death), and increased length of stay.

Importantly, the association between mental illness and physical health is bidirectional, resulting in a vicious cycle where either state may foster and support the onset of the latter. For example, new incidents of depression in cancer patients occur for a quarter of the population while for stroke patients the rate is around one in three (Spiegel \& Giese-Davis, 2003; Hackett et al., 2005; Raison \& Miller, 2003). In both cases, prevalence rises with severity of the physical symptoms (Hackett et al., 2005; Raison \& Miller, 2003). Furthermore, both asthma and COPD are significantly associated with a high prevalence of anxiety, panic and affective disorders (Livermore et al., 2010; Goodwin et al., 2003) and there is significant elevation in the rate of depression for people infected with HIV / AIDS (Ciesla \& Roberts, 2011), and for depression and anxiety disorders in people infected with the hepatitis $C$ virus (O'Dwyer et al., 2005). Evidently, services that can target the onset of mental illness in people with physical illness as well as vice versa will be important in tackling the problem of reduced outcomes, overall.

It is clear that international governments and social services need to take heed of this looming public health crisis and implement new strategies and services capable of breaking the cycle and preventing early deaths. However, the global health budget is not unlimited and therefore it is crucial that the strategies prioritised are taken forward, and are efficient, evidence-based, and flexible enough to draw significant outcomes from a variety of contexts. The only way these three criteria can be satisfied, is through a concrete understanding of the causes of reduced physical health in people with mental illness. Once these have been identified, we can have the best crack at addressing the primary triggers.

Plainly, one of the first considerations should be that mental illness itself may cause physical health problems, or that some shared aetiological factor results in both mental and physical symptoms. One mechanism of particular interest in this regard is the interaction of the brain with the endocrine system, particularly the regulation of stress hormones (Grippo \& Johnson, 2002). Structural and molecular brain changes associated with the progression of depressive symptoms, for example, are known to impair the hypothalamus' ability to inhibit the release of corticotrophin-releasing factor (Grippo \& Johnson, 2002; Reiche et al., 2004), a hormone that precedes and triggers the secretion of cortisol, adrenaline and noradrenaline, which are known stress hormones. Long-term elevated levels of these hormones are implicated in, among other things, metabolic dysfunction, immune system impairment, inflammation, and hypertension (Staufenbiel et al., 2013). Abnormal metabolism of glucose and fat, leading to obesity, combined with hypertension, creates a high-risk profile for CVD especially if symptoms are chronic. Meanwhile, a weakened cellmediated immune system response makes the body more susceptible to infectious disease and also less likely to eliminate tumour cells (Reiche et al., 2004). Concerningly, stress may also exacerbate depressive symptoms, perhaps through receptor desensitisation (Holsboer, 2001) or inflammation-induced tissue damage (Miller et al., 2009); possibly culminating in an everworsening positive feedback loop that impairs not only psychological symptoms but also physical health. It is interesting to note that the hypothalamic-pituitary-adrenal (HPA) axis also functions abnormally in other mental health conditions, potentially pointing to external stress as a common causal factor. This is at least supported in animal models where exposure to chronic stress is a significant predictor not only of affective symptoms but also immune suppression, reduced lifespan and tumour growth (Willner et al., 1992; Reiche et al., 2004).

Another way that the symptoms of mental illness may play a causal role in poor physical health is through lifestyle factors. On average, people with a mental illness consume more alcohol, tobacco (Szatkowski \& McNeil, 2013) and illegal drugs than equivalent mentallyhealthy populations, and they are also more likely to engage in liberal sexual practices. While the global use of tobacco has been declining, for example, a similar trend is barely perceptible in people with diagnosed mental illness (Szatkowski \& McNeil, 2013), and people with schizophrenia and depression are both more likely to smoke tobacco and consume it more heavily than members of the general population (Dani \& Harris, 2005). Being a current tobacco-smoker 
predicts a $20 \%$ reduced life expectancy, in addition to higher risk ratios for respiratory disease, CVD and cancer. Consequently, it has been estimated that close to $85 \%$ of deaths in people with severe mental illness can be attributed to use of tobacco (De Hert et al., 2011). Alcohol dependence is another commonly seen co-morbid substance use disorder in people with mental illness and is responsible for as many as 3.3 million deaths per year (World Health Organisation [no date]). Several studies have shown that having depression worsens alcohol abuse behaviour, either as a result of reduced motivation to abstain or as a form of self-medication against the depressive symptoms (Morris et al., 2012). There is a similar pattern for narcotics, particularly cannabis and cocaine, with use in patients with schizophrenia being not only higher than the general population but also likely to result in more inpatient stays (Menezes \& Mann, 1996). People with mental illness, especially those with anxiety disorders or depression, are generally more sensitised to the effects of stress and may actively seek out substances which induce relaxation. Stress sensitivity also makes cessation in drug addiction more difficult since experiences of stress are a common cause of relapse (Dani \& Harris, 2005).

Poor nutritional quality is a common observation in people with a mental illness. For example, people with schizophrenia are known to have diets generally higher in fat and refined sugar, while lower in fibre, fruits and vegetables (De Hert et al., 2011). Exacerbating this further, people with a mental illness are more likely to lead sedentary lives which may be partially attributable to social isolation acting as a barrier for community participation. Psychiatric patients are less likely to have a group of friends or to engage in community activities with the consequence that they miss out on common forms of physical exercise, as well as informal health monitoring from connections in the community. As a consequence of these factors, prevalence of obesity is higher than should be expected for this population (Scott \& Happell, 2011). For example, a study of a large cohort in the UK found that $35 \%$ of people with schizophrenia or a mood disorder could be diagnosed as being obese; nearly two times the rate of obesity rates is a general pattern across the world (Scott \& Happell, 2011).

There is pervading culture which wants to see lifestyle factors as unwise or irresponsible choices, however, often the opportunities available for people with a mental illness to live healthier lives are limited. For many people with mental illness around the world, lifestyle choices are restricted by stigma and human rights abuses. Stigmatisation comes in three main forms: (i) community-level stigma, (ii) purposeful discrimination from private or governing institutions, and, (iii) discrimination as an unintentional consequence of practice or policy (Corrigan et al., 2004). Community-level stigma often results when people do not understand the cause of mental illness and how it can be treated. Although possibly the product of innocent naivety, it can result in appalling abuses of human rights and diminishing opportunities for people with mental illness to lead a healthy life, such as rural families in the Philippines locking their relatives in cages. Purposeful discrimination from institutions can have similarly oppressive results for example with reduced access to employment found in countries such as Ghana and Belize driving people below poverty line (Drew et al., 2011). Accidental discrimination occurs in all countries and normally results from policymakers not considering the needs of people with mental illness when implementing new systems. This could be, for example, a failure to put in place support for people with mental illness who are interested in joining sports club or smoking cessation programmes.

One particularly pertinent source of stigma in the quest for improved physical outcomes in people with mental illness is access to healthcare. Across the globe, people with psychotic disorder, bipolar disorder and depression report difficulty accessing medical care, and it has become irrefutable that the rates of undiagnosed and untreated medical problems in people with mental illness are below the global average (De Hert et al., 2011). At one level particularly found in low- and middle-income countries (LAMIC), availability of appropriate health services is a problem, while in higher-income countries a greater problem is the lurking stigma or bias in practising clinicians. In LAMIC, mental health problems are still treated with a reduced level of urgency compared to what are considered more pressing medical conditions such as $\mathrm{HIV}$ / AIDS, malaria or tuberculosis, and in many countries there are very few, if any, mental health specialists available. Sparse laws addressing mental health and minimal funding mean that mental health programmes and services are not well-distributed across the country.

Far from being free of such problems, a number of affluent countries where there is no free healthcare provision also suffers from discri- 
mination in access to health services. In the US, for instance, citizens must pay into a health insurance package in order to make use of the healthcare system, but people with mental health problems are among the population to be least likely to have a health insurance plan in place. They are also far more likely than people in the general population to be from a relatively low economic background or homeless. Even in countries with free healthcare, however, there are implicit barriers to healthcare, namely fear of stigmatisation or judgement, mistrust of healthcare professionals, and reluctance to have symptoms investigated.

A possible main cause of these artificial barriers is a phenomenon known as diagnostic overshadowing. Whether due to bias, intentional stigma or a gap in training, the physical health problems of people with mental illness are less likely to get diagnosed accurately by medical professionals. It is feasible that a lack of knowledge, combined with hidden bias, could culminate in this effect. People with a mental health problem may not represent with the same range of clinical symptoms or make self-reports inconsistent with textbook diagnostic cases, potentially as a consequence of altered experiential states such as reduced pain threshold or cognitive deficits (De Hert et al., 2011). Furthermore, there may be a tendency to misattribute physical complaints as psychosomatic symptoms (De Hert et al., 2011). It is not only in diagnosis that people with mental illness are let down in this regard, however. A similar phenomenon has been shown to influence the range of physical treatments offered to people with mental illness. For example, in a study of people with ischaemic heart disease, those with co-morbid mental health illness were less likely to be offered a revascularisation procedure (Jones et al., 2008).

Another emerging iatrogenic contributor to lagging physical health in people with a mental illness is overmedication. There is growing evidence that pharmacological antidepressants such monoamine oxidase inhibitors and tricyclic antidepressants and, to a lesser extent, selective serotonin reuptake inhibitors, are cardiotoxins (Pacher et al., 2001; Tata et al., 2005; Taylor, 2008), giving rise to such side effects as orthostatic hypertension, arrhythmias and myocardial infarction (De Hert et al., 2011; Tata et al., 2005; Taylor, 2008). But perhaps even more problematic are the side effects resulting from treatments for psychotic disorders. Fre- quently used antipsychotics such as clozapine or olanzapine can have severe metabolic side effects and are known to be associated with greater propensity towards obesity and type II diabetes (Roshanaei-Moghaddam et al., 2009), both considerable risk factors for a range of other physical health problems. They can also contribute to the so-called metabolic syndrome which is extremely prevalent in people with schizophrenia, and which results in a three to six times increased risk of coronary heart disease (De Hert et al., 2011). Furthermore, use of antipsychotics is linked to the onset of extrapyramidal symptoms including tardive dyskinesia (De Hert et al., 2011). It has been suggested that through these side-effects and patients' attempts to self-medicate through activation of the dopamine system, antipsychotics contribute to the exacerbation of smoking and illicit drugusing habits and their associated physical health risks (Dani \& Harris, 2005). In addition, antipsychotic medications have been shown to elevate pain thresholds which are a possible reason for some physical health problems going unreported for extended periods (De Hert et al., 2011).

The reasons outlined here for lower physical health outcomes in people with mental illness are unlikely to paint the full picture, but they remain both the most commonly cited and most prevalent ideas on this topic. In summary, they can be grouped into four main categories: (i) physiological factors caused by or leading to the onset of mental illness; (ii) prevalent lifestyle factors; (iii) stigma or medical bias; and, (iv) overmedication. With these having been outlined, we will now move on to discuss an alternative system of interventions which could potentially lead to large-scale reduction in physical illness for this population.

Arguably, the most important step that will need to be taken to raise the physical health levels of people with mental illness is simply raising awareness among the health profession of the significant co-morbid risk factors for physical health problems among this population. Apart from enhanced mental health services there is little that can be done to minimise the enhanced risk of physical health problems caused by physiological effects of the mental health disorder. However, by being aware of these links and monitoring mental health patients, the physical health problems can be detected earlier, treated earlier and prevented from worsening. For example, the high association of major 
depression and bipolar disorders with cardiac symptoms are well-documented. If the awareness of this were spread among primary care clinicians and other health professionals, they may be more primed to look for cardiac symptoms in this population and more likely to detect them.

As has been seen, however, the interaction between mental illness and physical health conditions such as CVD is complex and consists of many different factors. With health budgets stretched across the globe and limitations in the time clinicians can devote to early monitoring, it is perhaps not feasible for all patients with a mental health condition to attend regular health check-ups. It is also an unnecessary commitment for both the patient and clinician if the individual risk profile is actually very small. Some authors have suggested that clinicians conduct one thorough medical examination on first contact with the patient and use the results of this to establish the risk and appropriate level of future medical monitoring (De Hert et al, 2011). The suggested measures include low-cost, low skill procedures such as taking a waist circumference, assessing alcohol and tobacco use and measuring blood pressure which could easily be carried out in lower income countries, as well as more technical processes such as determining fasting blood levels of glucose, lipids and prolactin or taking an electrocardiogram (ECG) which could be added to the medical examination where budgets, skills and technology allow. Assessing risk from these measures is a lot easier now that there are free online calculators available for clinicians (De Hert et al., 2011).

Technology has also advanced to the point where it is possible to screen patients' genomes for risk factors associated with physical disease. Access to this technology is likely to only be accessible to higher-income countries and even then will be expensive; however, it offers a finer grain of filtering for patients most at risk of developing physical health problems who can then have more resources put into monitoring and interventions. Whilst genomic tests will undoubtedly lead to more accurate results, a useful proxy for use in lower income countries and low-budget services elsewhere is to ask patients about their family history of physical health problems such as diabetes, CVD and cancer. Once risk profiles have been calculated, it is possible to prioritise future monitoring and service provision and more effectively prevent or treat physical health problems early.

Another factor that should be a trigger for more intensive monitoring is if the person has recently been started on psychotropic medication or if they have shown signs of an adverse reaction. Given the potentially life-threatening side-effects of common medications used in mental illness (e.g., antidepressants and antipsychotics), close monitoring of their suitability and effectiveness should be a priority in worldwide clinical practice. However, yet again, it is unreasonable and financially unfeasible to expect clinicians to monitor all patients on medication intensely and to expect patients to commit to it. A better strategy is to identify candidate patients who are at the highest risk of developing adverse symptoms. This includes drug-naive patients, children and adolescents as well as those with higher baseline levels of visceral fat and metabolic abnormalities (De Hert et al., 2011), most of which are factors that can be evaluated quickly and at low cost. Another solution to limited resources is to monitor all patients started on a new pharmacological treatment intensely (e.g., every week) for the first stage of treatment so that those patients who are reacting adversely can be detected. Conveniently, low cost measures such as waist circumference are useful indicators for onset of serious medical complications such as the metabolic syndrome so they can easily be measured in lower income countries. If adverse effects are detected, clinicians can decide to change the treatment to a more appropriate medication or consider concurrent psychological and lifestyle interventions to reduce the need for medication or lower its side effects.

Unfortunately, across the world, many people with a severe mental illness only have access to the healthcare system through mental health services and it has been well reported that many mental health professionals are reluctant to go beyond their station and expertise to monitor physical health. International guidelines to promote physical health screening by psychiatrists have previously been produced but have had minimal effect on practice. In this case, the better solution might be to move to a more collaborative care (CC) approach where physical health and mental health services are joined together with the result that by going to one clinic people with mental illness can see both a mental health specialist and physical health specialist who then communicate with each other to coordinate care.

Psychologically-supported programmes designed specifically for people with mental illness 
that aim to reduce overeating, smoking, use of drugs and alcohol, and promote social inclusion and exercise. Charity and support group engagement to promote social inclusion and access to activities. First that needs to be addressed is the increased clinician awareness of the comorbid risk factors for people with a mental illness. For example, doctors should be more primed to look for cardiac symptoms in people with depression or bipolar disorder. Common genomic associations between depression and risk factors for cardiac disease could be learned by clinicians and then applied in practice to look for risks. Maybe regular health check-ups based on these risks for people with a diagnosed mental health problem. For many people with severe mental illness, the only access to healthcare is through the mental health team.

Though guidelines have been agreed and published, many psychiatrists are reluctant to go beyond their station and monitor physical health. In addition, low cost monitoring can include an initial profiling of genetic risk; patients can be asked about their family history with regards to diabetes mellitus, CVD, hypertension and cancer. Psychologicallysupported programmes designed specifically for people with mental illness that aim to reduce overeating, smoking, use of drugs and alcohol, and promote social inclusion and exercise.

Teaching and training settings can be structured to convey a message of hope and recovery rather than on focusing on the person served in negative terms, as belligerent, resistant, unmotivated, or disinterested. Trainers should carefully construct 'real-play' experiences rather than 'role plays'. A real-play exercise has the trainee in the 'client' seat, describing his or her own life situation, personal values, strengths, goals, and challenges. In contrast, in role plays, the trainee pretends to be a 'real client', often portrayed in a pejorative manner as resistant, unmotivated, and challenging. By contrast, in well-designed real-play situations, the trainee discovers that many 'problems' or 'issues' experienced by people served parallel to what they, themselves, have experienced. Through real-play practice, trainees come to see these difficulties and challenges as common human nature issues, creating empathy for the people they serve. A real play can offer a transformative learning experience (Nemec, 2015) - an experience that creates disruption, such as facing a contradiction in what the learner 'knows' to be true.

Many international guidelines for the monitoring of physical health measures in people with mental illness have already been drawn up but they are rarely implemented in clinical practice. A more simple option is to take baseline measures of any patient who enters into psychiatric care and identify those at elevated risk of diabetes or CVD. If the patient is started on medication, it has been suggested that they should be monitored every week for the initial periods of treatment. This can highlight patients who are gaining weight rapidly and prompt medication review or alternative interventions. Thereafter a health check every three months can be offered to those progressing through treatment without any significant side effects or health risk profiles.

More training in mental health indicators in hospital settings and availability of psychological support screening, engagement, education of patients and family members, close follow-up, and tracking of adherence and clinical outcomes shows that many of the required skills and tasks of care can be learned and delivered by a range of non-specialist health workers with appropriate training and supervision. Particular skills, such as case finding, support of treatment adherence and motivational coaching, follow-up tracking, patient education, and self-management support, turn out to be quite critical to providing effective care. These 'care management tasks' or work packages can be effectively assigned to nonspecialist health workers who are well positioned to bring them into the community, extending the reach of primary care. Several recent metaanalyses have concluded that Collaborative Care (CC), the best-evaluated model for treating common mental disorders such as depression or anxiety in primary care settings, is consistently more effective than care as usual United Kingdom, Canada, the United States, and the Netherlands, there is a growing evidence base testifying to its applicability in primary care in LAMIC.

Changes in dietary composition can have substantial effects. Weight loss has many healthrelated benefits that are of particular importance to (severe mental illness) SMI patients, including a reduction in risk of diabetes mellitus and CVD, reduction of serum triglycerides and LDL-cholesterol concentrations, increase in HDL-cholesterol concentrations, and reduction in blood glucose concentrations and haemoglobin A1c among patients with type 2 DM. However, interventions that address nutrition, weight management and physical activity have not 
become a routine part of psychiatric care 98 . The psychiatrist can involve the individual with SMI in educational and psychosocial programs that address the issues of health and wellness, which can reduce medical comorbidities in this population. These programmes, such as 'The Healthy Living' programme, the 'Small Changes' strategy and the 'Solutions for Wellness' programme have been shown to be effective in people with SMI.

Cessation of smoking is associated with approximately a $50 \%$ decrease in the risk of coronary heart disease 104, and a 75\% decrease in the risk of high/very high 10-year cardiovascular events 126. Therefore, SMI patients should be strongly encouraged to stop smoking. Moreover, treatments that work in the general population appear to be approximately equally effective in SMI patients. The evidence also suggests that treating tobacco dependence in SMI patients with stable psychiatric conditions does not worsen mental state 133. Finally, although staff from psychiatric hospitals often express concerns that adopting a smokefree policy would have a negative impact on the hospital's treatment milieu, this is not necessarily the case 134 . Therefore, at a minimum, psychiatric professionals should assess tobacco use in all patients, advise all tobacco users to quit, assist patients in developing a quit plan, and arrange follow-up 100. If necessary and possible, patients can be referred to a smoking cessation service, which can offer behavioural counselling, nicotine replacement therapy or other pharmacological interventions.

One study (Park et al., 2013) has revealed that Spanish-supervised walking group study for women with depression. Supervised walking was highly cost effective at $\$ 449$ (` 311, 2005 prices) per QALY gained, with a $99.9 \%$ probability of being cost effective assuming a cost per QALY threshold of just $\$ 865$ ( ${ }^{\circ} 600,2003$ prices). Furthermore, in this context nurses and other health care professionals such as physical health and lifestyle trainers that routinely work closely with people with mental health problems can focus more on looking at factors that may encourage greater sustained participation in health-promoting activities (Park et al., 2013).

A 'Quality and Outcomes Framework' (QOF) governs the performance-related component of GPs' funding, where performance is assessed against a number of specified targets. This rewards GPs financially for recording every 15 months that they have advised smokers with schizophrenia, bipolar disorder and other psychoses to quit or referred them to a specialist smoking cessation adviser (Szatkowski \& McNeil, 2013)

A higher annual prevalence of advice recording was seen in smokers with schizophrenia, schizotypal, delusional and bipolar disorders is unsurprising, given the financial incentives to do so, although was present in fewer than twothirds of cases despite the QOF payment thresholds rewarding recording in up to $90 \%$ of eligible patients. The lower proportion of consultations in which advice is recorded or cessation medication prescribed may suggest that, given equal opportunity to do so, GPs appear less likely to intervene with smokers with indicators of poor mental health compared to those without. The smoking cessation interventions which are known to work in the general population have also been shown to be effective in patients with poor mental health, suggesting that primary health-care professionals should target interventions towards their patients with mental health disorders. If these professionals were to intervene in an equal proportion of consultations regardless of patients' health status, smokers with indicators of poor mental health would be advised to quit or prescribed a cessation medication more frequently over the course of a year, which may help to reduce the smoking prevalence and resulting health inequalities in these vulnerable groups of patients. (Szatkowski \& McNeil, 2013)

Another aspect that should be taken into account, considering that it is already the digital age, is the impact of blogs on mental health i.e., blog psychology (Relojo, 2017). It is generally recognised that blogging started in 1994, with Links.net considered to be the first ever blog. Since then blogs on a variety of topics and disciplines have emerged. Undeniably, blogs have been a functional vehicle in promoting psychology and have been instrumental in promoting mental health. Psychology and mental health blogs offer a wealth of information, insight, and interesting content for their audience. The range, immediacy, and diversity of bloggers' voices are highly compelling; readers are often drawn to blogs for their speed and intimacy. In light of this, the present paper outlines how blogs can serve as a transformative medium to promote the discipline of psychology and allied fields. It also provides a brief account of psychology blogs and provides an overview of popular blogs in the discipline. A new field 
could potentially materialise in the discipline and this can be known as 'blog psychology': a sub-branch of the discipline that attempts to apply psychological principles and research, including research partnership (Relojo, 2015) in order to optimise the benefits that readers can derive from consuming blogs. Potential theories of blog psychology may incorporate the readers' perception, cognition, and humanistic components in regards to their experience to consuming blogs. It could also explore a range of psychological principles involved in running blogs.

The proportion of SMI patients not receiving tests for assessing metabolic risk factors, even for factors relatively simple and easy to measure, such as obesity and blood pressure, is high 141,177,178,179,180,181. At present, neither psychiatrists nor primary care physicians carefully screen or monitor patients receiving angina pectoris (AP) medication for metabolic risk factors 173. Even after FDA (Food and Drug Administration) and ADA (American Diabetes Association)/APA (American Psychiatric Association) recommendations for novel $\mathrm{AP}$, the frequency of baseline glucose and lipid testing showed little change. Several large-scale pharmacoepidemiologic studies of individuals initiating a novel AP (with non-psychiatric large control groups) reported low mean baseline metabolic testing rates, varying between $8 \%$ and less than 30\% 181,182,183 and follow-up assessments done in only $8.8 \%$ of patients. Likewise, most children starting treatment with novel AP do not receive recommended glucose and lipid screening. In a related study in children receiving AP treatment, similarly low metabolic monitoring rates were found 184 .

There is a vicious cycle between mental illness and physical illness. Having a mental illness increases the chances of developing a physical illness and vice-versa. Greater monitoring, understanding and interventions can help reduce the severity of the physical symptoms but it seems the best way to break the cycle is to create more mentally-friendly communities. As what has been illustrated on this discourse, mental health is co-morbid with substance abuse - either drug abuse or sexual abuse. Also, there is a greater likelihood that of alcohol dependence among people with psychiatric disorders compared to the general population. Essentially, some individuals with mental health issues may find it challenging to engage with primary care services, whereas some do not consider their substance use as a problem and are therefore uncooperative to access specialist substance misuse services. Hence, one of the interventions that could be utilised to address this is promoting a culture change among mental health key persons, such as mental health nurses and assistant psychologists. A pre-requisite to working effectively with people with substance use issues is to create a non-judgemental and collaborative relationship. Also, involved people should work in partnership with substance misuse services to build referral pathways and treatment options that are accessible and tailored to the needs of different individuals with mental health problems.

Interventions that target specific groups or that are tailored to the individual, taking into account the participant's age, gender, socioeconomic status, cultural background, health status, barriers to activity, and fitness level, are more effective in increasing levels of physical activity than more generic interventions. It could be argued that physical health is reduced for people with mental illness because the disease is detected later. People with a mental illness may not seek medical help because of stigma, misattributing symptoms or abnormal sensory experience e.g. reduced pain thresholds.

Mental health and physical health are so interlinked, maybe it is unhelpful to think of them as two separate entities and just focus on promoting health in general. The reintegration of psychiatric care and general somatic services, with an ultimate goal of providing optimal services to this vulnerable patient population, seems to represent one of the most important challenges for psychiatric care today. Integrated treatment programmes in which medical providers are supported to treat common mental health problems offer a chance to treat 'the whole patient', an approach that is more patientcentred and often more effective than an approach in which mental health, acute and chronic physical health, reproductive health, and chronic pain problems are each addressed in a different 'silo' without effective communication between providers. Second, integrated care programmes that can address patients' mental health needs in the context of general or other specialised health care settings are often more attractive to patients and family members who are concerned about the stigma that is still associated with mental and substance abuse disorders and the treatment settings that specialise on caring for individuals with severe mental disorders. 


\section{REFERENCES}

Campayo, A., Gymez-Biel, C. H., \& Lobo, A. (2011). Diabetes and depression. Current Psychiatry Reports, 13(1), 26-30. https://doi.org/10.1007/s11920-010-0165-z

Ciesla, J. A., \& Roberts, J. E. (2001). Meta-analysis of the relationship between HIV infection and risk for depressive disorders. American Journal of Psychiatry, 158(5), 725-730.ttps://doi.org/10.1176/appi.ajp.158.5.725

Corrigan, P. W., Markowitz, F. E., \& Watson, A. C. (2004). Structural levels of mental illness stigma and discrimination. Schizophrenia Bulletin, 30(3), 481-491. ttps://doi.org/10.1093/oxfordjournals.schbul.a007096

Crump, C., Sundquist, K., Winkleby, M. A., \& Sundquist, J. (2013). Comorbidities and mortality in bipolar disorder: A Swedish national cohort study. JAMA Psychiatry, 70(9), 931-939. https://doi.org/10.1001/ jamapsychiatry.2013.1394

Curkendall, S. M., Mo, J., Glasser, D. B., Rose, S. M., \& Jones, J. K. (2004). Cardiovascular disease in patients with schizophrenia in Saskatchewan, Canada. The Journal of Clinical Psychiatry, 65(5), 715-720. https://doi.org/ 10.4088/jcp.v65n0519

Dani, J. A., \& Harris, R. A. (2005). Nicotine addiction and comorbidity with alcohol abuse and mental illness. Nature Neuroscience, 8(11), 1465-1470. https://doi.org/ 10.1038/nn1580

De Hert, M., Cohen, D., Bobes, J., Cetkovich?Bakmas, M, Leucht, S., Ndetei, D.M.,... \& Gautam, S. (2011). Physical illness in patients with severe mental disorders. II. Barriers to care, monitoring and treatment guidelines, plus recommendations at the system and individual level. World Psychiatry, 10(2), 138-151. https://doi.org/10.1002/ j.2051-5545.2011.tb00036.x

Drew, N., Funk, M., Tang, S., Lamichhane, J., Chбvez, E., Katontoka, S., ...\& Saraceno, B. (2011). Human rights violations of people with mental and psychosocial disabilities: an unresolved global crisis. The Lancet, 378(9803), 1664-1675. https://doi.org/10.1016/s01406736(11)61458-x

Frasure-Smith, N., \& Lespŭrance, F. (2010). Depression and cardiac risk: present status and future directions. Heart (96)3, 173-176. https://doi.org/10.1136/hrt.2009.186957

Golden, J., O’Dwyer, A. M., \& Conroy, R. M. (2005). Depression and anxiety in patients with hepatitis $\mathrm{C}$ : prevalence, detection rates and risk factors. General Hospital Psychiatry, 27(6), 431-438. https://doi.org/ 10.1016/j.genhosppsych.2005.06.006

Goodwin, R. D., Jacobi, F., \& Thefeld, W. (2003). Mental disorders and asthma in the community. Archives of General Psychiatry, 60(11), 1125-1130. https://doi.org/ 10.1001/archpsyc.60.11.1125

Goldstein, B. I., Fagiolini, A., Houck, P., \& Kupfer, D. J. (2009). Cardiovascular disease and hypertension among adults with bipolar I disorder in the United States. Bipolar Disorders, 11(6), 657-662. https://doi.org/10.1111/j.13995618.2009.00735.x

Grippo, A. J., \& Johnson, A. K. (2002). Biological mechanisms in the relationship between depression and heart disease. Neuroscience \& Biobehavioral Reviews, 26(8), 941-962. h https://doi.org/10.1016/s01497634(03)00003-4

Hackett, M. L., Yapa, C., Parag, V., \& Anderson, C. S. (2005). Frequency of depression after stroke. Stroke, 36(6),
$1330-1340$

01.str.0000165928.19135.35

https://doi.org/10.1161/

Hennekens, C. H., Hennekens, A. R., Hollar, D., \& Casey, D. E. (2005). Schizophrenia and increased risks of cardiovascular disease. American Heart Journal, 150(6), 1115-1121. https://doi.org/10.1016/j.ahj.2005.02.007

Himelhoch, S., Lehman, A., Kreyenbuhl, J., Daumit, G., Brown, C., \& Dixon, L. (2004). Prevalence of chronic obstructive pulmonary disease among those with serious mental illness. American Journal of Psychiatry, 161(12), 2317-2319. https://doi.org/10.1176/appi.ajp.161.12.2317

Hodgson, R., Wildgust, H. J., \& Bushe, C. J. (2010). Cancer and schizophrenia: is there a paradox? Journal of Psychopharmacology, 24(4_suppl), 51-60. https://doi.org/ 10.1177/1359786810385489

Holsboer, F. (2001). Stress, hypercortisolism and corticosteroid receptors in depression: implicatons for therapy. Journal of Affective Disorders, 62(1), 77-91. https://doi.org/10.1016/s0165-0327(00)00352-9

Hughes, E., Bassi, S., Gilbody, S., Bland, M., \& Martin, F. (2016). Prevalence of HIV, hepatitis B, and hepatitis C in people with severe mental illness: a systematic review and meta-analysis. The Lancet Psychiatry, 3(1), 40-48. https://doi.org/10.1016/s2215-0366(15)00357-0

Joukamaa, M., HeliЦvaara, M., Knekt, P., Aromaa, A., Raitasalo, R., \& Lehtinen, V. (2001). Mental disorders and cause-specific mortality. The British Journal of Psychiatry, 179(6), 498-502. https://doi.org/10.1192/bjp.179.6.498

Kastrup, M. C., \& Ramos, A. B. (2007). Global mental health. Danish Medical Bulletin, 54(1), 42-43. https:// doi.org/10.1002/9780470746738.ch22

Kolappa, K., Henderson, D. C., \& Kishore, S. P. (2013). No physical health without mental health: lessons unlearned? Bulletin of the World Health Organization, 91(1), 3-3a. https://doi.org/10.2471/blt.12.115063

Kovacs, A. H., Saidi, A. S., Kuhl, E. A., Sears, S. F., Silversides, C., Harrison, J. L., ... \& Nolan, R. P. (2009). Depression and anxiety in adult congenital heart disease: predictors and prevalence. International Journal of Cardiology, 137(2), 158-164. https://doi.org/10.1016/ j.ijcard.2008.06.042

Lawrence, D., Hancock, K. J., \& Kisely, S. (2013). The gap in life expectancy from preventable physical illness in psychiatric patients in Western Australia: retrospective analysis of population based registers. British Medical Journal, 346, f2539. https://doi.org/10.1136/bmj.f2539

Livermore, N., Sharpe, L., \& McKenzie, D. (2010). Prevention of panic attacks and panic disorder in COPD. European Respiratory Journal, 35(3), 557-563. ttps:// doi.org/10.1183/09031936.00060309

Miller, A. H., Maletic, V., \& Raison, C. L. (2009). Inflammation and its discontents: the role of cytokines in the pathophysiology of major depression. Biological Psychiatry, 65(9), 732-741. https://doi.org/10.1016/ j.biopsych.2008.11.029

Moran, P., Stewart, R., Brugha, T., Bebbington, P., Bhugra, D., Jenkins, R., \& Coid, J. W. (2007). Personality disorder and cardiovascular disease: results from a national household survey. The Journal of Clinical Psychiatry, 68(1), 69-74. https://doi.org/10.4088/jcp.v68n0109

Menezes, P. R., \& Mann, A. H. (1996). Mortality among patients with non-affective functional psychoses in a metropolitan area of south-eastern Brazil. Revista de Saude Publica, 30(4), 304-309. https://doi.org/10.1590/s0034- 
89101996000400003

Morris, D. W., Budhwar, N., Husain, M., Wisniewski, S. R., Kurian, B. T., Luther, J. F., ... \& Trivedi, M. H. (2012). Depression treatment in patients with general medical conditions: results from the CO-MED trial. The Annals of Family Medicine, 10(1), 23-33. https://doi.org/ 10.1370/afm.1316

Nemec, P. B., Swarbrick, M., \& Legere, L. (2015). Prejudice and discrimination from mental health service providers. Psychiatric Rehabilitation Journal, 38(2), 203 206. https://doi.org/10.1037/prj0000148

Pacher, P., Kohegyi, E., Kecskemeti, V., \& Furst, S. (2001). Current trends in the development of new antidepressants. Current Medicinal Chemistry, 8(2), 89100. tps://doi.org/10.2174/0929867013373796

Pinto-Coelho, A. (2017). Mental health needs and access to mental health services in Portugal: Some optimism, some pessimism. Psychreg Journal of Psychology, 1(1), 64-74.

Raison, C. L., \& Miller, A. H. (2003). Depression in cancer: new developments regarding diagnosis and treatment. Biological Psychiatry, 54(3), 283-294. https:// doi.org/10.1016/s0006-3223(03)00413-x

Reiche, E. M. V., Nunes, S. O. V., \& Morimoto, H. K. (2004). Stress, depression, the immune system, and cancer. The Lancet Oncology, 5(10), 617-625. https://doi.org/ 10.1016/s1470-2045(04)01597-9

Relojo, D. (2017). Blog psychology: Insights, benefits, and research agenda on blogs as a dynamic medium to promote the discipline of psychology and allied fields. Psychreg Journal of Psychology, 1(2), 70-75.

Relojo, D., dela Rosa, R., \& Pilao, S.J. (2016). Current developments in reading abilities through phonological processing skills and proficiency in a second language. $i$ manager's Journal on Educational Psychology 10(2), 45-54

Relojo, D. (2015, October 23). Building and promoting research partnership: interview with Scott Furtwengler [Blogpost]. Retrieved from https://web.archive.org/web/ 20160323085903/https://blog.piirus.com/2015/10/23/ building-and-promoting-research-partnership-aninterview-with-scott-furtwengler/

Rimington, L. D., Davies, D. H., Lowe, D., \& Pearson, M. G. (2001). Relationship between anxiety, depression, and morbidity in adult asthma patients. Thorax, 56(4), 266 271. ttps://doi.org/10.1136/thorax.56.4.266

Roest, A. M., Martens, E. J., de Jonge, P., \& Denollet, J. (2010). Anxiety and risk of incident coronary heart disease: a meta-analysis. Journal of the American College of Cardiology, 56(1), 38-46. https://doi.org/10.1016/ j.jacc.2010.03.034

Roshanaei-Moghaddam, B., \& Katon, W. (2009). Premature mortality from general medical illnesses among persons with bipolar disorder: a review. Psychiatric Services, 60(2), 147-156. https://doi.org/10.1176/ appi.ps.60.2.147

Roshanaei-Moghaddam, B., Katon, W. J., \& Russo, J. (2009). The longitudinal effects of depression on physical activity. General Hospital Psychiatry, 31(4), 306-315. https://doi.org/10.1016/j.genhosppsych.2009.04.002

Spiegel, D., \& Giese-Davis, J. (2003). Depression and cancer: mechanisms and disease progression. Biological Psychiatry, 54(3), 269-282. https://doi.org/10.1016/s00063223(03)00566-3
Staufenbiel, S. M., Penninx, B. W., Spijker, A. T., Elzinga, B. M., \& van Rossum, E. F. (2013). Hair cortisol, stress exposure, and mental health in humans: a systematic review. Psychoneuroendocrinology, 38(8), 1220-1235. https://doi.org/10.1016/j.psyneuen.2012.11.015

Szatkowski, L., \& McNeill, A. (2013). The delivery of smoking cessation interventions to primary care patients with mental health problems. Addiction, 108(8), 14871494. ttps://doi.org/10.1111/add.12163

Tata, L. J., West, J., Smith, C., Farrington, P., Card, T., Smeeth, L., \& Hubbard, R. (2005). General population based study of the impact of tricyclic and selective serotonin reuptake inhibitor antidepressants on the risk of acute myocardial infarction. Heart, 91(4), 465-471. https:// doi.org/10.1136/hrt.2004.037457

Taylor, D. (2008). Antidepressant drugs and cardiovascular pathology: A clinical overview of effectiveness and safety. Acta Psychiatrica Scandinavica, 118(6), 434-442. https://doi.org/10.1111/j.16000447.2008.01260.x

Tran, E., Rouillon, F., Loze, J.Y., Casadebaig, F., Philippe, A., Vitry, F., \& Limosin, F. (2009). Cancer mortality in patients with schizophrenia. Cancer, 115(15), 3555-3562. ttps://doi.org/10.1002/cncr.24383

Van Der, S.., Wilma, M.A., Nieuwenhuijsen, C., Van Den Berg?Emons, R.J., Bergen, M.P., Hilberink, S.R.,...\& Roebroeck, M.E. (2012). Chronic pain, fatigue, and depressive symptoms in adults with spastic bilateral cerebral palsy. Developmental Medicine \& Child Neurology, 54(9), 836-842. https://doi.org/10.1111/j.14698749.2012.04371.x

Walker, E. R., McGee, R. E., \& Druss, B. G. (2015). Mortality in mental disorders and global disease burden implications: a systematic review and meta-analysis. JAMA Psychiatry, 72(4), 334-341. https://doi.org/10.1001/ jamapsychiatry.2014.2502

Wang, H., Naghavi, M., Allen, C., Barber, R.M., Bhutta, Z.A., Carter, A.,...\& Coggeshall, M. (2016). Global, regional, and national life expectancy, all-cause mortality, and cause-specific mortality for 249 causes of death, 1980 2015: a systematic analysis for the Global Burden of Disease Study 2015. The Lancet, 388(10053), 1459-1544.

Willner, P., Muscat, R., \& Papp, M. (1992). Chronic mild stress-induced anhedonia: a realistic animal model of depression. Neuroscience \& Biobehavioral Reviews, 16(4), 525-534. https://doi.org/10.1016/s0149-7634(05)80194-0

World Health Organization. [no date] Premature death among people with severe mental disorders. Retrieved from: http://www.who.int/mental_health/management/ info_sheet.pdf

\section{АНОТАЦІЯ}

\section{Релоджсо Деніс.}

Виміри вдосконалення фізичного здоров'я у людей 3 розумовими вадами.

У статті аналізуються результати нещодавно здійсненого метааналізу смертності серед пацієнтів із психічними захворюваннями, який показує, що стан психічного здоров'я утримує $14,3 \%$ ризику, а отже відповідає за понад 8 млн. щорічних випадків смерті в усьому світі, що перевершує випадки ішемічної хвороби серця, 
інсульту, хронічного обструктивного захворювання легенів та ВІЛ / СНІД. Доведено, що цей величезний рівень смертності частково зумовлений підвищеною ймовірністю того, що люди із психічними захворюваннями самі створюють проблеми для власного фізичного здоров'я. Особливо це стосується серцево-судинних захворювань, що на сьогоднішній день є найбільшим джерелом смертності у світі, пов'язаної з хворобами, де діагностика депресивного розладу або шизофренії зустрічається в два з половиною рази частіше та може бути ще вищою у людей з біполярним розладом. У дослідженні аргументована виняткова роль міжнародних урядів та соціальних служб, яким слід прислухатися до цієї гострої кризи здоров'я громадян та впроваджувати нові стратегії і послуги, здатні подолати вказаний руйнівний цикл і запобігати раннім смертям. Однак глобальний бюджет на охорону здоров'я є обмеженим, i тому важливо, щоб стратегії, на які поширюються пріоритети, були б усе ж таки впроваджені та ефективні, засновані на безсумнівних доказах і достатньо гнучкі, щоб залучити значні надходження з різних контекстів соціально-економічного життя. Сдиний спосіб задовольнити ці критерії- конкретне розуміння причин зниження фізичного здоров'я людей із психічними захворюваннями. Психічне та фізичне здоров'я це настільки взаємопов'язані складники, що небажано думати про них як про два окремі суб'єкти, а потрібно зосереджуватись на підвищенні здоров'я окремої людини в цілому. Реінтеграція психіатричної допомоги та діяльності загальносоматичних служб з метою надання оптимальних послуг для цієї вразливої категорії населення (пацієнтів), здається, є однією з найважливіших проблем психіатричної допомоги сьогодення. Запропоновані інтегровані програми лікування, за допомогою яких медичні заклади підтримують здолання спільних проблем психічного здоров'я, дають шанс зреалізовувати комплексний підхід до здоров'я пацієнта, який орієнтований на його особистість i часто більш ефективний, ніж диференційований підхід, коли психічне, фізичне і репродуктивне здоров'я та хронічні проблеми з болем вирішуються в різних контекстах життєдіяльності людського організму без ефективного спілкування між представниками різних медичних закладів.

Ключові слова: психічні розлади, психічні захворювання, смертність, фізичне здоров'я, шизофренія, депресія, рак.

\section{ANNOTATION}

\section{Relojo Dennis.}

Dimentions of improvement the physical health of people with mental illness.

The article analyzes a recent meta-analysis of mortality in mental illness, which has concluded that mental health conditions constitute a population attributable risk (PAR) of $14.3 \%$ and are, therefore, responsible for more than 8 million annual deaths worldwide, ahead of ischaemic heart disease, stroke, chronic obstructive pulmonary disease (CORP) and HIV/AIDS. It is proved that this huge death rate is partially attributable to an increased likelihood of people with a mental illness developing physical health problems. This is particularly the case in cardiovascular disease (CVD), by far the largest contributor to worldwide disease-related mortality, where diagnosis is as much as two and a half times more likely for people with major depressive disorder or schizophrenia, and may yet be even higher for people with bipolar disorder. It is clear that international governments and social services need to take heed of this looming public health crisis and implement new strategies and services capable of breaking the cycle and preventing early deaths. However, the global health budget is not unlimited and therefore it is crucial that the strategies prioritised are taken forward, and are efficient, evidence-based, and flexible enough to draw significant outcomes from a variety of contexts. The only way these three criteria can be satisfied, is through a concrete understanding of the causes of reduced physical health in people with mental illness. Mental health and physical health are so interlinked, maybe it is unhelpful to think of them as two separate entities and just focus on promoting health in general. The reintegration of psychiatric care and general somatic services, with an ultimate goal of providing optimal services to this vulnerable patient population, seems to represent one of the most important challenges for psychiatric care today. Integrated treatment programmes in which medical providers are supported to treat common mental health problems offer a chance to treat 'the whole patient', an approach that is more patientcentred and often more effective than an approach in which mental health, acute and chronic physical health, reproductive health, and chronic pain problems are each addressed in a different 'silo' without effective communication between providers.

Key words: mental disorders, mental illness, mortality, physical health, schizophrenia, depression, cancer.

Рецензенти:

д. психол. н., проф. Болтівець С.І., д. психол. н., проф. Москалець В.П.

Надійшла до редакції 09.01.2018. Підписана до друку 05.03.2018. 